\title{
Characteristics of Students in Three Schools of General Education and Council of Christian Churches of Angola in the City of Huambo-Angola on Sexuality for Educational Intervention
}

\section{Natércia Paulina S. de Almeida ${ }^{1}$, Carolina Lino da Silva1, José R. Molina Garcia1, Alberto Capoco Sachiteque1, Welema Cipriano da Fonseca1, Carla Ramalho², Frederico João Carlos Juliana ${ }^{3}$, Cezaltina Naduva Kahuli ${ }^{4}$, Hamilton dos Prazeres Tavares ${ }^{5 *}$}

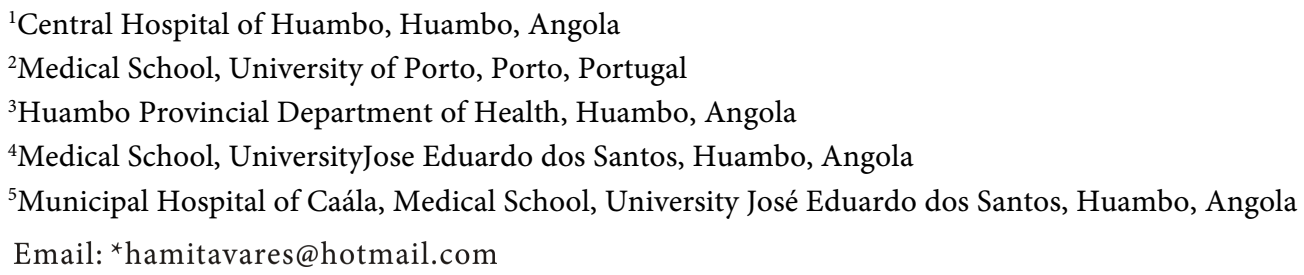

How to cite this paper: de Almeida, N.P.S., da Silva, C.L., Garcia, J.R.M., Sachiteque, A.C., da Fonseca, W.C., Ramalho, C., Juliana, F.J.C., Kahuli, C.N. and dos Prazeres Tavares, H. (2016) Characteristics of Students in Three Schools of General Education and Council of Christian Churches of Angola in the City of Huambo-Angola on Sexuality for Educational Intervention. Open Journal of Obstetrics and Gynecology, 6, 572-587.

http://dx.doi.org/10.4236/ojog.2016.610073

Received: July 2, 2016

Accepted: August 23, 2016

Published: August 26, 2016

\begin{abstract}
Sexual education is a social responsibility and is a part of the coherent strategy referred to the introduction in schools in Angola. It was made of a prospective, descriptive and longitudinal study that has been characterized the knowledge of sexual education of students in general education in three schools and the Council of Christian Churches in Huambo-Angola in July 2015. The sample consisted of 386 students chosen randomly; there are no sexual education programs in the education system, there are taboos on sexuality, the respondents do not know the sexual organs and much less contraceptive methods, there are still taboos in sexuality theme approach with adolescents, the results showed.
\end{abstract}

\section{Keywords}

Characterization, Students, Schools, Knowledge, Sexuality

\section{Introduction}

Sexuality is a concept in dispute, historically there are several definitions, varying from 
Copyright $\odot 2016$ by authors and Scientific Research Publishing Inc. This work is licensed under the Creative Commons Attribution International License (CC BY 4.0).

http://creativecommons.org/licenses/by/4.0/ location, environment, education, training, area of knowledge, experiences and ideals, takes particular accents as the reference to sex, which is intertwined with different times of life. According to Heilborn [1], one of the first forms of classification in the social world comes from human sexuality. The word "sex", however, can have several meanings: it can designate the physical format of bodies, male or female of the species, but also sexual activity. Sexuality is one of the dimensions of the human being that involves gender, sexual identity, sexual orientation, eroticism, emotional involvement, love and reproduction. It is experienced or expressed in thoughts, fantasies, desires, beliefs, attitudes, values, activities, practices, roles and relationships. In addition to the consensus that the social and cultural components are critical to the concept of human sexuality, there is a clear trend in theoretical approaches that sexuality refers not only to the reproductive capacities of human beings, as well as the pleasure. Thus, it is life itself. It involves, beyond our body, our history, our customs, our personal relationships, our culture [2].

Sex education is the most important way to prevent problems related to sexual and reproductive health of young people, according to age and culturally relevant level of education to address issues related to sexual and emotional relationships, which provide the first information scientifically correct, realistic and without losses. It frees and awakens interest in opportunities to explore their own values and attitudes to develop skills and make decisions, communicate and reduce the risks in human sexuality, instead, with good education are not lost dreams, we contribute better to economy world in such a way that allows good academic differentiation, plan the children and family [3] [4].

Sexuality is an integral part of life of each individual and contributes to its identity throughout life and for their physical and psychological balance. The WHO proclaim, is an energy that motivates us to seek love, contact, tenderness, intimacy, which is integrated in the way we feel, move, touch and are touched. It is to be sensual and sexual at the same time. It influences thoughts, feelings, actions and interactions, and therefore also influences our physical and mental health [5].

Sexually transmitted diseases are a new issue of concern for world governments discussed aspect rigorously in sexual education [6].

Teenage pregnancy is a public health problem in the universe, and sexual education is possible to reverse this situation and fearing the complications that it comes, such as specific hypertensive syndrome of pregnancy, delivery dystocia, bleeding, etc. [7] [8].

Family planning is an instrument with sufficient scientific evidence regarding the cost-benefit results in the reduction of unwanted and early pregnancy, induced abortion rate and the maternal mortality direct causes of death in our countries, as, respects the inter genesic intervals and defines the desired number of children, etc. [6].

The age of initiation of sexual relations varies from one country to another, according to regional and cultural values. In Brazil, $64 \%$ of adolescent males and 13\% females aged from 15 to 17 years are sexually active. Thus, the sexual activity of adolescents at an early age is an indicator of pregnancy, a phenomenon that is happening in all countries, in increasing frequency, according to the Ministry of Health. In Angola, the 
average age of onset of sexual relations in women it is 12 years old [9].

\subsection{Lack on Sexual Education and Consequences.}

Lack on sexual education results in poverty, gives spaces to early and unwanted pregnancies. The repercussions can be social (abandonment labor and school activities), Psychological (depression, suicide) Biological (early closure of growth records and sexually transmitted diseases), Health (pregnancy diseases and increased morbidity in maternal and infant mortality) [9].

Induced Clandestine induced abortion (unsecure), is a major cause of maternal mortality and puts at risk especially women in developing countries where abortion is restricted by law, and in countries where, although legally permitted, safe abortion is not easily accessible. It is estimated that $13 \%$ of all maternal deaths worldwide are due to unsafe abortion [10]. According to the World Health Organization (WHO), every 1000 women of childbearing age ( 15 to 44 years), 29 induced abortion at some point in life. Approximately $1 / 3$ of the 205 million pregnancies that occur worldwide each year are unintended and $20 \%$ end an induced abortion [10]. The reliable data deficiency on abortion, however, is understandable in countries where abortion is illegal, because the record can lead to serious consequences, both for women who practice it, as for the person who performed the procedure. Thus, the statistics are based mainly on the number of women attending public hospitals; however, these figures may be higher [11].

Globally, estimates of unsafe abortion rates by regions shows that the highest incidence by groups of 1000 women between 15 and 49 years of age is observed in Latin America (26/1000), followed by Africa (22/1000) and Asia (11/1000). Considering the regions within each continent, the highest rate is found in South America (30/1000), followed by East Africa (29/1000), West Africa (24/1000) and South and Central Asia (20/1000). The abortion rate insecure in more developed regions is $2 / 1000$ [12].

\subsection{Negative Restrictions on Sexuality}

Various interpretations have been put forward to explain why many young people continue to have sex without protection, such as the following:

1) Few or no presence of sexual education programs in schools;

2) Sexuality based on taboos or religious prejudices, distanced from the reality of young people;

3) Parental resistance by considering promoting sexuality a dialogue on this subject between teachers and students;

4) Lack of information about fertility regulation;

5) Lack of clarity about the modes of transmission of STD/AIDS;

6) Few or no access to contraception, including emergency contraception (morning after pill), which provides within 72 hours after intercourse, can prevent an unwanted pregnancy;

7) Lack of dialogue on sexuality within the family;

8) Conflict of generations, in which the older people do not speak the language of 
young people;

9) The need for self-assertion via maternity and/or paternity;

10) Lack of external stimuli that expand horizons and mobilize the individual potential of young people to the formulation of life projects;

11) Lack of knowledge on the perceptions and representations that young people have of themselves and the world around them [13] [14].

\section{Material and Methods}

This is a prospective, longitudinal and descriptive study, which aimed to identify the knowledge of the sexual organs and sexuality on students of IST Secondary School Cycle in three schools and Council of Christian Churches in Huambo City in July 2015 for further educational intervention. The sample consisted of 386 students chosen randomly among students mostly from the $8^{\text {th }}$ grade. It is a validated survey in the service of Gynecology and Obstetrics of the Huambo Central Hospital.

VARIABLE: sex, age, school grade, school, residence, marital status, profession/occupation; female gynecological history as knowledge of menstruation, menarche age, regular menstrual period, previous pregnancies, previous abortion; in both sexes; have or have had boyfriend/girlfriend, if you have had sex, how far reached, age at first intercourse, knowledge of contraceptive methods and of the genital organs, functions of some organs, mention three contraceptive methods; and boy, have had pregnant girl. The chosen schools were those located in the neighborhoods around the Referral Hospital to facilitate the movement of researchers who are medical in full service at this hospital. Questionnaires were administered for one month, the month of July classes a day in each school prior to negotiation with the Directorate of each school and parents. As time classes, they were applied on Saturday not to interfere with school activities and was applied on a Sunday after Mass, in the case of students of the CICA, prior to negotiation with the General Secretary of the Council of Christian Churches in Huambo.

They were included: Students who could read and write and participate with correct completion of personal data in the form, for those under 18 years of age, who had permission from the parent.

The participation on these was at free will, those who participated, they were given a written informed consent document. This document explained the purpose of the work and informed the right to choose to participate or not, it was also explained that the data results would be exclusively used for this study, and that identities would not be disclosed and that would be fulfilled with the confidentiality professional. The study variables were grouped into:

socio-demographic-age, sex, marital status, occupation, education gynecological and obstetrical history-menarche, beginning of sexual intercourse, first pregnancy, abortion, anatomy of sexual organs, family planning-contraceptive.

\section{Results}

The sample was 386 students chosen in a random and probabilistic way. The number of 
students per school was: São Francisco de Assis 114, Commander Bula 85, Teresianas Plus 88 from the Council of Christian Churches (CICA) 99 students respectively.

\section{Discussion}

Table 1 shows the demographic data of students, where 50.8\% (196/386) were girls and $49.2 \%$ (190/386) boys. The largest number of students was in the range of $14-16$ years with $37 \%$ (143) in both sexes followed by $11-13$ years with 124 (32.1\%). The marital status was single $94 \%$ (363) and only studying, that is, most were student with $87.6 \%$ (338).

This table shows that mostly the classes in which we work, that is, IST Secondary School Cycle specifically to $8^{\text {th }}$ grade, the ages was 11 to 16 years; It was achieved the desired balancing the sample in both sexes with $50.8 \%$ girls and $49.2 \%$ boys; almost all of them were students $87 \%$ (338/386) and $94 \%$ (363/386) only that activity, without any other type of employment, and marital had not bond since the teenagers should not have other activities labor or be forced into early marriage, these problems are very common in rural areas of our country, which is contrary to the rights of the child ratified by our country on the international organizations, to protect them from child labor with or without remuneration and promulgates the right to education up to 18

Table 1. Socio-demographic data of students in three schools and the CICA in Huambo, for later educational intervention on knowledge of the genital organs and sexuality in July 2015.

\begin{tabular}{cccc}
\hline & & & $\%$ \\
\hline Sex N (386) & Female & 196 & 50.8 \\
& Male & 190 & 49.2 \\
\hline Age N (386) & $\leq 10$ & 1 & 0.3 \\
& $11-13$ & 124 & 32.1 \\
& $14-16$ & 143 & 37.0 \\
& $17-19$ & 62 & 16.1 \\
Marital status N (386) & $\geq 20$ anos & 56 & 14.5 \\
& Married & 8 & 2.1 \\
& Single & 363 & 94.0 \\
& Marital & 15 & 3.9 \\
\hline Occupation N (386) & Public agent & 3 & 0.8
\end{tabular}


years and free decision and choice of the future partner.

Studies in Brazil in 14 schools in the Federal Capital, the women prevailed, 54.2\% against $45.8 \%$ for boys. Ages in this study were slightly balanced, $40.9 \%$ of $10-14$ and $51.5 \%$ aged 15 - 19 years [15].

Table 2 illustrates the sexual and gynecological history of students, where if the girls had sex 75.5\% (148/196) said no; if got pregnant 91.3\% (179) answered no; if menstruating, $85.7 \%$ (168) said yes; if have had abortion $97.4 \%$ (191) said no and knowing what menstruation is $79.6 \%$ (156) answered yes; the age of first sexual intercourse $68.1 \%$ (263/386) left blank; age at first menstruation, most of the girls was in the range of 11 13 years with 78\% (153/196); as boys, if had have sex 84.2\% (160/190) answered yes; got a girl pregnant $88.4 \%$ (168) said no.

These results suggest to us that teenagers say what does not compromise them, since the questions about sexual or gynecological issues that are not taboos, answered in most cases, as in the case about menstruation and the age of beginning, the rest of the questions, prefer not to answer.

A survey in 2004 found that Brazilian adolescents have started early sexual life and maintained a greater number of partners. According to the Ministry of Health in 2006, $36 \%$ of young people aged 15 - 24 reported having had their first sexual intercourse before age 15 , while only $21 \%$ of young people aged $25-29$ years had the first relationship at the same time. Of these, $20 \%$ reported having had more than ten partners in their lives and

Table 2. Sexual history of students in the three schools and the CICA in the city of Huambo, for later educational intervention on sexuality in July 2015.

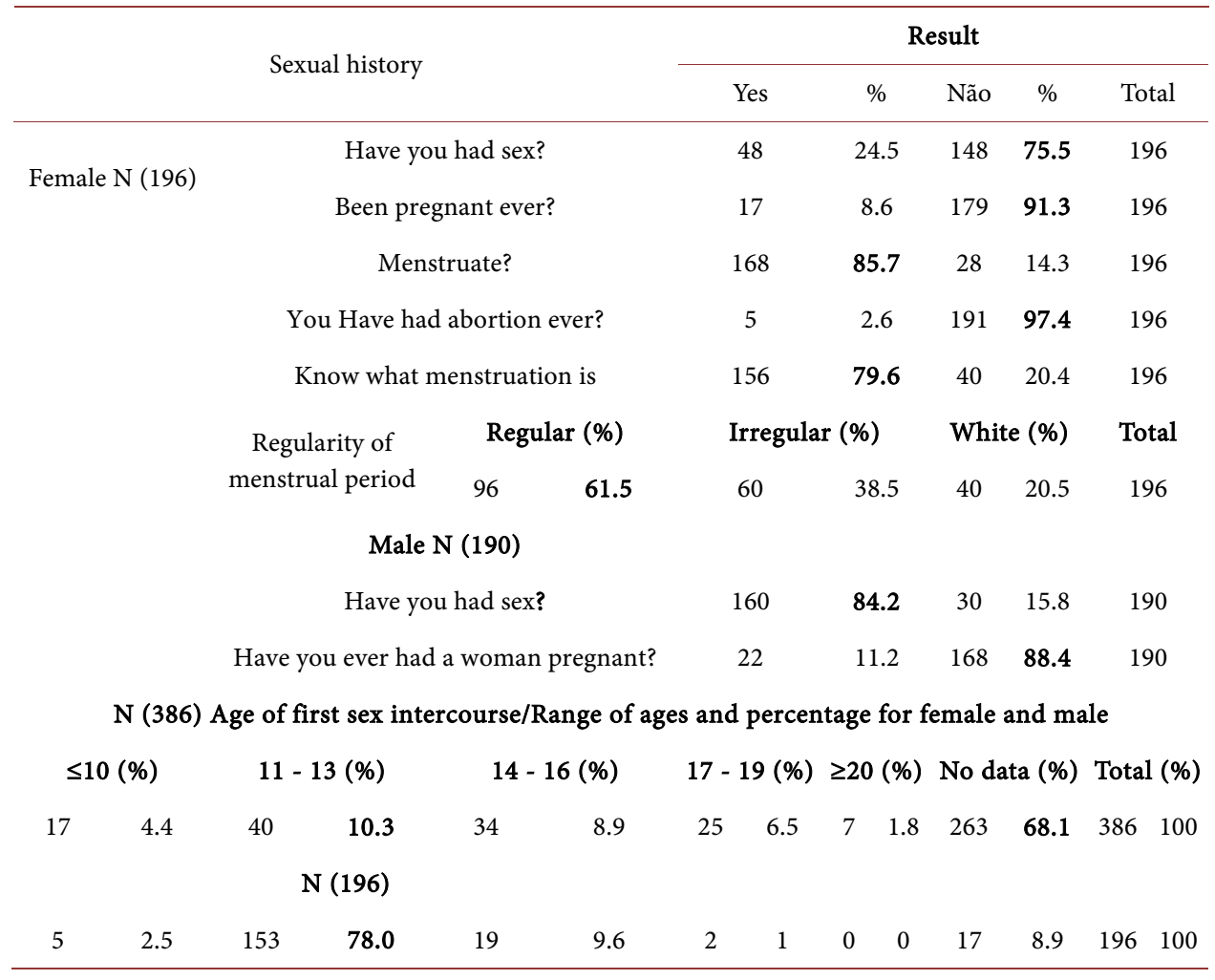


7\% had more than five sexual partners in the last year [16]. Another study in Brazil in 14 Federal Capital schools for mapping sexuality related issues, indicated that more than half of young males, had their first sexual intercourse in the range between 10 and 14 years. However the girls mostly have their first sexual intercourse between 15 to 19 years [15]. Despite the girls majority 75.5\% (148/196) say not having sex, draws attention the boys $84.2 \%$ (160) already had, and here is a question for us. Who the boys have sex with? The task is further studies can clarify these discrepancies, so we can reach more reliable conclusions. UNFPA in 2002, the beginning of sexual relations in Angola between 11 and 12 years old, which creates conditions for unwanted pregnancies and the practice of abortion [16].

Regarding menstruation, knowledge and age of onset, the results go according to the literature, which states increasingly early onset of sexual secondary characteristics including menstruation in girls [17].

Sexuality in the school environment is a controversial topic, given the multiplicity of views, beliefs and values of the various stakeholders (students, parents, teachers and principals, among others), therefore, the taboos and interdictions that socially and historically dogging issues that are related, pervade the time. As recorded in the survey in some countries, for some parents, school is no place to teach bosses, but also documents that most parents, and in greater proportion teachers and students, are favorable to the discussion of sexuality in schools. Pereira, notes that, "in the minds of parents, teachers and students, the dyad sexuality education is almost invariably an exotic ingredient in a diet end, indigestible". For some authors, the school's intervention in the field of sexuality as well as complex, has risks, considering that the school is intrinsically oriented disciplinary conduct, emphasis on reason and control [17].

Already sexuality asks observation desires, individuation and attention to the thin line between pleasure, libido and drives and set limits for such individual guidelines do not endanger civilizing projects, coexistence and the rights of others. It suggests, psychoanalysts and psychologists, the school difficulties in developing sexual orientation projects or tap the theme would be based on conflicts between reason and culture, on the one hand, and feeling and drives the other, referred to in Freud and Reich. This dilemma is thus mentioned in the communication manual. To analyze the relationship between sexuality and school is almost equivalent to articulate the poles of an antithesis. The school has been shown to be persistently refractory to the impact of which was called by Reich "sexual revolution". Perhaps this reflects the essential antagonism between sexuality and culture postulated by Freud, or modernization of inability of the educational institution [17].

Certainly gender results are a pioneering contribution to the understanding of the processes that block or hinder the healthy communication, constructive and humane between generations.

Thus, the research will open new avenues for the proper formulation of programs that increase the level and coverage of knowledge in the area of sexuality and reproductive health with teachers and family; also influence the proposed policies to disseminate and 
allow access among young people the means to practice protected sex. But above all, it paves safer ground where they can live the aspirations, hopes and dreams with the vigor of youth and their sexualities [12].

Table 3 shows the answers as to whether or not have had complete sex and the age at distinct school and sex. Girls, abstained to answer in $60.7 \%$ (119/196) and over half of boys answered yes $50.6 \%(96 / 190)$; in relation to age these complete sexual relations, $75.5 \%$ (148) of the girls did not answer and the boys most who answered yes were between 11 - 13 years with $22.6 \%$.

Table 3. Sexual history of students per school and the CICA in the city of Huambo, for later educational intervention on sexuality in July 2015.

\begin{tabular}{|c|c|c|c|c|c|c|c|c|c|c|c|}
\hline \multirow{3}{*}{\multicolumn{3}{|c|}{ sexual history per school }} & \multicolumn{8}{|c|}{ School } & \multirow{3}{*}{$\begin{array}{c}\text { Total } \\
\mathrm{N}\end{array}$} \\
\hline & & & \multicolumn{2}{|c|}{$\begin{array}{c}\text { São Francisco } \\
\text { de Assis }\end{array}$} & \multicolumn{2}{|c|}{$\begin{array}{c}\text { Comandante } \\
\text { Bula }\end{array}$} & \multicolumn{2}{|c|}{$\begin{array}{c}\text { Irmãs } \\
\text { Teresianas }\end{array}$} & \multicolumn{2}{|c|}{ CICA } & \\
\hline & & & $\mathrm{N}$ & $\%$ & $\mathrm{~N}$ & $\%$ & $\mathrm{~N}$ & $\%$ & $\mathrm{~N}$ & $\%$ & \\
\hline \multirow{9}{*}{$\begin{array}{c}\text { Have you } \\
\text { had complete sex? }\end{array}$} & & Yes & 21 & 10.7 & 19 & 9.6 & 6 & 3 & 14 & 7.1 & 60 \\
\hline & Female & Not & 8 & 4 & 7 & 3.5 & 1 & 0.5 & 1 & 0.5 & 17 \\
\hline & N (196) & $\begin{array}{c}\text { no } \\
\text { information }\end{array}$ & 48 & 24.5 & 21 & 10.7 & 27 & 13.7 & 23 & 11.7 & 119 \\
\hline & \multirow{5}{*}{$\begin{array}{c}\text { Male } \\
\text { N (190) }\end{array}$} & Total & 77 & 39.2 & 47 & 24 & 34 & 17.3 & 38 & 19.4 & 196 \\
\hline & & Yes & 28 & 14.8 & 21.0 & 11 & 8 & 4.2 & 39 & 20.6 & 96 \\
\hline & & Not & 7 & 3.6 & 17 & 9.0 & 1 & 0.6 & 12 & 6.3 & 37 \\
\hline & & $\begin{array}{c}\text { no } \\
\text { information }\end{array}$ & 9 & 4.8 & 21 & 11.0 & 12 & 6.3 & 15 & 7.8 & 57 \\
\hline & & Total & 44 & 23.2 & 59 & 31.0 & 21 & 11.0 & 66 & 34.8 & 190 \\
\hline & \multicolumn{11}{|c|}{ Age of the first sexual intercourse age ranges; number and percentage } \\
\hline \multirow{12}{*}{$\begin{array}{c}\text { Age of the first } \\
\text { sexual intercourse }\end{array}$} & \multirow{12}{*}{$\begin{array}{c}\text { Male } \\
\text { N (190) }\end{array}$} & $1-13$ & 3 & 1.5 & 1 & 0.5 & 4 & 2.0 & 4 & 2.0 & 12 \\
\hline & & $14-16$ & 16 & 8.1 & 0 & 0 & 3 & 1.5 & 6 & 3.0 & 25 \\
\hline & & $17-19$ & 3 & 1.5 & 0 & 0 & 0 & 0 & 8 & 4.0 & 11 \\
\hline & & Brano & 17 & 8.6 & 31 & 15.9 & 79 & 40.4 & 21 & 10.7 & 148 \\
\hline & & Total & 39 & 19.9 & 32 & 16.4 & 86 & 43.9 & 39 & 19.8 & 196 \\
\hline & & $\leq 10$ & 6 & 3.2 & 10 & 5.2 & 1 & 0.6 & 6 & 3.2 & 23 \\
\hline & & $11-13$ & 11 & 5.8 & 10 & 5.2 & 17 & 9.0 & 5 & 2.6 & 43 \\
\hline & & $14-16$ & 9 & 4.8 & 9 & 4.9 & 6 & 3.2 & 12 & 6.3 & 36 \\
\hline & & $17-19$ & 3 & 1.6 & 1 & 0.6 & 11 & 5.8 & 19 & 10.0 & 34 \\
\hline & & $\geq 20$ & 1 & 0.6 & 1 & 0.6 & 0 & 0 & 5 & 2.6 & 7 \\
\hline & & $\begin{array}{c}\text { no } \\
\text { information }\end{array}$ & 17 & 9.0 & 12 & 6.3 & 11 & 5.8 & 7 & 3.6 & 47 \\
\hline & & Total & 47 & 24.8 & 43 & 22.6 & 46 & 24.2 & 54 & 28.4 & 190 \\
\hline
\end{tabular}


As the national survey in 1996 Demographic and Health held in Brazil, the data showed the median age for first intercourse of 19.5 for women and 16.7 for men. More recent data collected by the Brazilian Center for Analysis and Planning in 1999, showed that young people have been starting much earlier sex life. It has been mentioned in Table 2, the UNFPA in 2002 this early sexual activity in Angola between 11 and 12 years old, which confirms our results [13].

Youth is a time when the trial of sexuality will enable structuring of identity. Thus, prejudices and beliefs organize sexual-affective possibilities of youth. According to Abramovay recognizes sexuality as social construction is similar to saying that the practices and desires are also culturally constructed, depending on the diversity of people, worldviews and existing customs; even when integrated into a single country, as in Brazil and Angola. This involves the need for questioning mainly present ideas in habits and ancestral customs, in idealized behaviors that are "naturalized", and thus generalized to all social groups, regardless of their origin and location. Youth is also decisive for cycle demarcation of gender differences in the field of identity. Such differences can enhance creativity, uniqueness as may tend to play sexualized divisions with asymmetry and inequality connotation. It is therefore natural that significant literature in the field of sexuality has been directed to the place of school and youth education. Therefore, it is necessary that in the level of Angola, continues to appeal the state and other institutions, the need to continue to invest in ways to address gender issues in schools and beyond, in order to reduce fear and negative reactions generated with power purposes outline the best strategies for future implementation of sexual education programs [12].

Table 4 demonstrates the answers as to conceive if ever had previous abortions, regularity or irregularity of the menstrual period and the differences between schools; we see a large proportion of girls do not respond 47\% (92/196); left blank the question if already pregnant; $44.4 \%$ (87); of those who said yes, the highest percentage was in CICA $6.1 \%$ (12); in boys, 60.6\% (115/190) said not have had woman pregnant; those who answered yes, the largest number was also in CICA 10.6\% (20); as if abortion had directed to the girls, $40.9 \%$ (80/196) said no and $56.6 \%$ (111) left blank, those that said yes, most were from CICA $2.0 \%$ (4); as the regularity of menstruation $49 \%$ (96) was regular. Unpublished studies at national level do not confirm these results. The study in Huambo Central Hospital in 2012, revealed a high incidence of abortions in patients that occurred in emergency services of the Department of Obstetrics and Gynecology between 2010-2013, which were carried out 7222 clandestine post-abortion curettage, over $90 \%$ were from urban areas in Huambo province and $69.3 \%$ were aged from 13 to 25 years [1].

It is important for teenager to know and relate the menstrual cycle, sex and pregnancy, since they are essential to make attitude toward sex behavior and the proper and rational use of contraceptive methods. One reason which leads to unwanted pregnancy is obviously not relating these elements. For obstetricians and gynecologists, it is important to take the girl early days of the monthly registration and end of menstruation, since from 
Table 4. gynecologic history of students in the three schools and the CICA in the city of Huambo, for later educational intervention on sexuality in July 2015.

\begin{tabular}{|c|c|c|c|c|c|c|c|c|c|c|c|c|}
\hline \multicolumn{3}{|c|}{ Have you had pregnant ever? } & \multicolumn{2}{|c|}{$\begin{array}{c}\text { São Francisco } \\
\text { Assis }\end{array}$} & \multirow{2}{*}{$\begin{array}{c}\text { Comandante } \\
\text { Bula }\end{array}$} & \multicolumn{3}{|c|}{$\begin{array}{c}\text { Irmãs } \\
\text { Teresianas }\end{array}$} & \multicolumn{2}{|c|}{ CICA } & Total & \\
\hline \multirow{4}{*}{\multicolumn{2}{|c|}{$\begin{array}{l}\text { N (196) } \\
\text { Female }\end{array}$}} & Yes & 5 & 2.5 & & 0 & 0 & 0 & 12 & 6.1 & 17 & 8.6 \\
\hline & & Not & 25 & 12.7 & 24 & 12.2 & 30 & 15.4 & 13 & 6.6 & 92 & 47.0 \\
\hline & & White & 17 & 8.6 & 23 & 11.7 & 37 & 18.9 & 10 & 5.1 & 87 & 44.4 \\
\hline & & Total/\% & 47 & 24.0 & 47 & 24.0 & 67 & 34.1 & 35 & 17.9 & 196 & 100.0 \\
\hline \multirow{4}{*}{ N (190) } & \multirow{4}{*}{ Male } & Yes & 0 & 0 & 3 & 1.6 & 0 & 0 & 20 & 10.6 & 23 & 12.1 \\
\hline & & Not & 53 & 27.8 & 35 & 18.4 & 3 & 1.6 & 24 & 12.6 & 115 & 60.6 \\
\hline & & White & 17 & 9.0 & 19 & 10.0 & 11 & 5.8 & 5 & 2.6 & 52 & 27.4 \\
\hline & & Total/\% & 70 & 36.8 & 57 & 30.0 & 14 & 7.4 & 49 & 25.8 & 190 & 100.0 \\
\hline \multirow{4}{*}{$\begin{array}{l}\text { Have had abortion } \\
\text { ever? N (196) }\end{array}$} & \multirow{4}{*}{ Female } & Yes & 1 & 0.5 & 0 & 0 & 0 & 0 & 4 & 2.0 & 5 & 2.5 \\
\hline & & Not & 15 & 7.6 & 13 & 6.6 & 21 & 10.7 & 31 & 15.9 & 80 & 40.9 \\
\hline & & White & 33 & 16.9 & 41 & 21.0 & 27 & 13.7 & 10 & 5.1 & 111 & 56.6 \\
\hline & & Total/\% & 49 & 25.0 & 54 & 27.5 & 48 & 24.5 & 45 & 23.0 & 196 & 100.0 \\
\hline \multirow{4}{*}{$\begin{array}{l}\text { Regularity of menstrual } \\
\text { period N (196) }\end{array}$} & \multirow{4}{*}{ Female } & Reg & 26 & 13.2 & 10 & 5.1 & 18 & 9.1 & 42 & 21.5 & 96 & 49.0 \\
\hline & & Irreg & 22 & 11.2 & 7 & 3.5 & 26 & 13.2 & 5 & 2.5 & 60 & 30.6 \\
\hline & & $\begin{array}{c}\text { No } \\
\text { information }\end{array}$ & 16 & 8.1 & 11 & 5.6 & 7 & 3.5 & 6 & 3.0 & 40 & 20.5 \\
\hline & & Total \% & 64 & 32.6 & 28 & 14.2 & 51 & 26.0 & 53 & 27.0 & 196 & 100.0 \\
\hline
\end{tabular}

that are programmed sections for administration of drugs in stimulating ovulation in patients treated for infertility. Moreover, the knowledge thereof, provides physicians with useful tools for guiding and prescribe large part of hormonal contraceptives and not only, which depend for their administration, the time of the menstrual cycle. By way of example, if the girl knew the menstrual, regular or irregular period, it would be suggested and given a type and not the other, in dependence on that, in the specific case to be irregular, the better we would use combined hormonal methods that help regulate the period which can betray a better control of fertile day. In this same case, it would also be wise to use male or female condoms, if forget to administer the pill or injection. In the case of regular periods, we could choose to use barrier methods (condoms) in sterile period and sexual abstinence during the fertile period, since it is not advisable to use hormonal methods in adolescence, which could interfere with the normal operation neuro hormonal girl (hypothalamic-pituitary-ovarian-axis endometrium) that still does not complete its development [9].

Table 5 shows the results if you have had boyfriend/girlfriend, where they have had the sex life, the knowledge on three contraceptive methods: regarding whether or had a boyfriend, 37.5\% (145/386) of the girls left blank; yes it was equivalent 15.5 (60) and $15.2 \%$ (59) between girls and boys respectively; in girls yes majority was in São Francisco and Irmãs Teresianas (19); and in boys was in São Francisco de Assis (21) and CICA (19); 
Table 5. Sexual history of students in three schools and the CICA in the city of Huambo for further educational intervention on sexuality in July 2015.

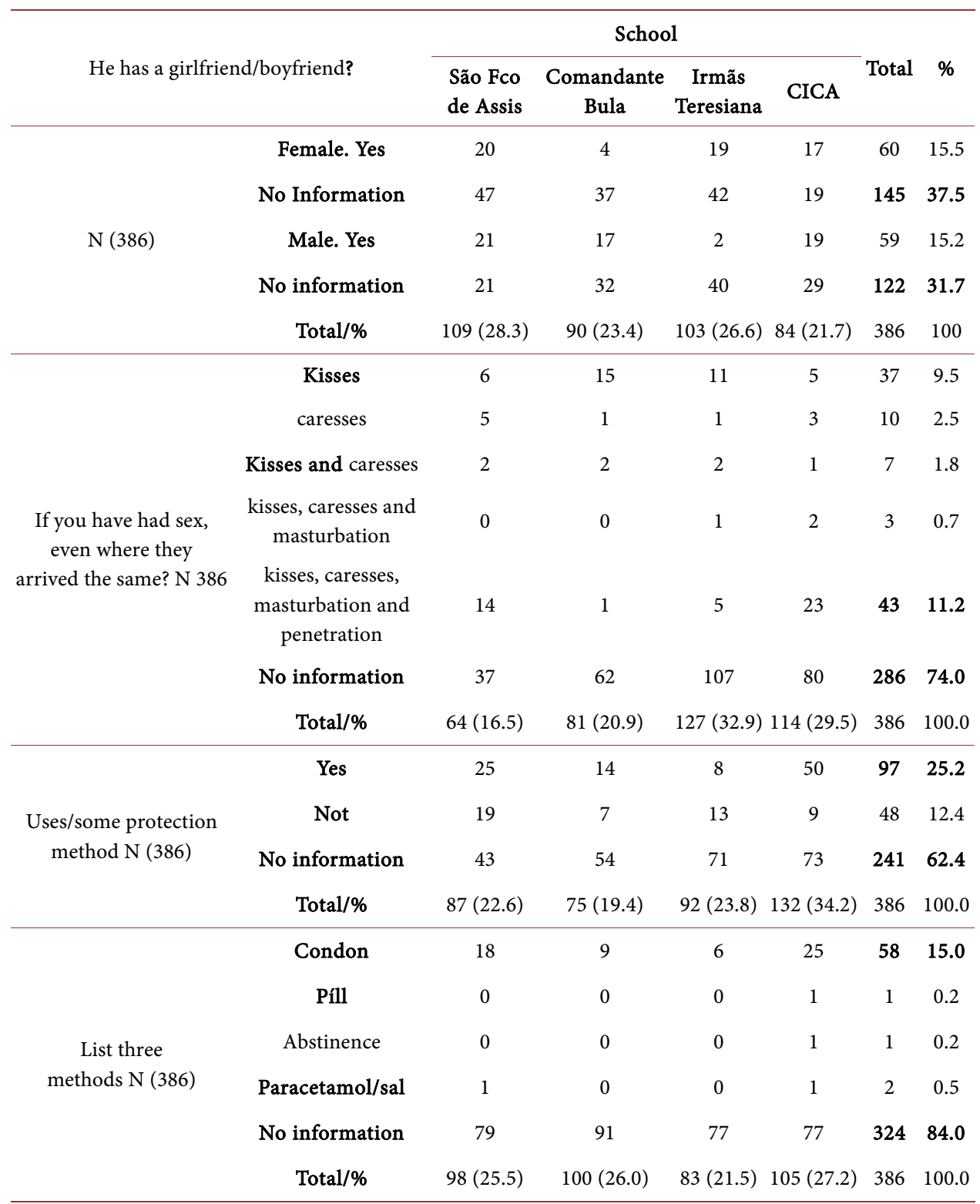

how far reached sex to those who already had, 74\% (286/386) left blank; Who said to have reach to the penetration with the highest percentage in CICA (23) and San Frascisco of Assis(14). If you used a contraceptive method, 62.4\% (241/386) left blank; 25.2\% (97) said yes; not answer to this question was similar in San Francisco (43); Comandate Bula (54); Irmãs Teresianas (71) and CICA (73); who knew contracceptive methods, the majority belonged to the CICA (50); to mention them, $84 \%$ (324/386) left blank; the method mentioned mostly was condoms $15 \%$ (58); none of the students could mention three (3) contraceptives.

These results corroborate those of Table 4, there is obviously a total ignorance. Future studies need to take out of ways to be able to collect more comprehensive answers. Our 
view is certainly the students to be afraid to express themselves. Yes we had or have a boyfriend/girlfriend, was equivalent between girls and boys 15.5\% (60) and 15.2\% (59); the other most keenly questions not answered 74\% (286/386) about how far sexual intercourse was; as the differences in school, there were no significant differences, some had only kissed, other kissing and fondling, masturbation and some even full penetration, which we considered to be the ultimate expression in the sexual attitudes of young people. Also, it was observed that students of São Francisco de Assis School, despite being under age, there was an inconsiderable number who accepted reach penetration $3.7 \%(14 / 386)$ similar to most adults in CICA 5.9\% (23/386).

A study in Portugal, showed different results regarding the students' knowledge of the various contraceptive methods, where 53\% said they used pills and $45 \%$ male condoms [11]. In Angola, the study in Huambo Central Hospital in 2012 not published showed $10 \%$ of the women surveyed used a contraceptive method [9].

According to WHO data, about $19 \%$ of young women in developing countries become pregnant before age 18 and girls under 15 years account for 2 million of the 7.3 million births that occur in adolescents younger than 18 each year in developing countries [16]. We think that the reasons for these problems are obviously lack of preventive education of adolescents in these countries, on the one hand there are no programs in schools that can educate them on matters such as sexual and emotional relationships and on the other hand, the practice of sex penetrative is increasingly early and without knowledge and use of contraception [18].

Table 6 illustrates the classification according to the students' knowledge of their genital organs and functioning. As it can be seen, all had the bad rating, both to identify the organs themselves and the opposite sex; for girls, the highest percentage was $28.5 \%$ (56/196) for their organs and 24\% (47) for the male organs; as the boys, 30\% (57/190) and $32.6 \%(62 / 190)$ for the female organs respectively; there were no significant variations between institutions.

We intended it to verify the knowledge in the aspects evaluated, not only the constitution of the genitals and functions of some organs but also of contraceptive methods. Obviously the results confirmed what was assumed, a general ignorance of themselves and the opposite sex even for the young people of greater age attending churches [16].

Several authors and surveys indicate that the proportion of teenage mothers who did not plan the pregnancy varies widely from one region to another and in the same region. In Latin America and the Caribbean, $25 \%$ to $50 \%$ of young mothers report having unplanned pregnancy; in the countries of northern Africa and the Middle East, the ratio ranges from about $15 \%$ to $30 \%$. About $10 \%$ to $16 \%$ of pregnancies adolescents in India, Indonesia and Pakistan are not intended, while in other Asian countries the proportion ranges from $20 \%$ to $45 \%$. The variation is even higher in sub-Saharan Africa; from $11 \%$ to $13 \%$ in Niger and Nigeria, $50 \%$ or more in Botswana, Ghana, Namibia, Kenya and Zimbabwe [19].

Many countries have taken up the cause of preventing teenage pregnancy, often through actions aimed at changing behavior of girls. Implicit in such interventions a belief that the girl is responsible for preventing pregnancy and an assumption that if she 
Table 6. Knowledge rating in 3 schools and CICA in Huambo municipality about the genitals and functions for later educational intervention on sexuality in July 2015.

\begin{tabular}{|c|c|c|c|c|c|c|c|}
\hline \multirow{2}{*}{\multicolumn{2}{|c|}{$\begin{array}{l}\text { Recognition and classification of } \\
\text { genital organs and functions }\end{array}$}} & \multicolumn{6}{|c|}{ School } \\
\hline & & $\begin{array}{l}\text { São Francisco } \\
\text { de Assis }\end{array}$ & $\begin{array}{l}\text { Comandante } \\
\text { Bula }\end{array}$ & $\begin{array}{c}\text { Irmãs } \\
\text { Teresianas }\end{array}$ & CICA & Total & $\%$ \\
\hline \multirow{9}{*}{$\begin{array}{l}\text { Female } \\
\mathrm{T}=196\end{array}$} & Good & 5 & 8 & 3 & 1 & 17 & 8.6 \\
\hline & Regular & 2 & 4 & 3 & 3 & 12 & 6.1 \\
\hline & Bad & 25 & 18 & 2 & 11 & 56 & 28.5 \\
\hline & No information & 7 & 6 & 4 & 5 & 22 & 11.2 \\
\hline & Good & 5 & 6 & 4 & 1 & 16 & 8.1 \\
\hline & Regular & 0 & 2 & 2 & 2 & 6 & 3.0 \\
\hline & $\mathrm{Bad}$ & 7 & 13 & 14 & 13 & 47 & 24.0 \\
\hline & No Information & 6 & 4 & 6 & 4 & 20 & 10.2 \\
\hline & Total & $57(29.0)$ & $61(31.1)$ & $38(19.4)$ & $40(20.5)$ & 196 & 100 \\
\hline \multirow{9}{*}{$\begin{array}{c}\text { Male } \\
\mathrm{T}=190\end{array}$} & Good & 6 & 4 & 2 & 1 & 13 & 6.8 \\
\hline & Regular & 1 & 1 & 2 & 5 & 9 & 4.8 \\
\hline & $\mathrm{Bad}$ & 9 & 15 & 21 & 12 & 57 & 30.0 \\
\hline & No Information & 4 & 3 & 2 & 1 & 10 & 5.2 \\
\hline & Good & 5 & 5 & 2 & 4 & 16 & 8.4 \\
\hline & Regular & 2 & 1 & 3 & 6 & 12 & 6.3 \\
\hline & Bad & 7 & 11 & 22 & 22 & 62 & 32.6 \\
\hline & No Information & 3 & 2 & 4 & 2 & 11 & 5.8 \\
\hline & Total & $37(19.4)$ & $42(22.1)$ & $58(30.6)$ & $53(27.9)$ & 190 & 100 \\
\hline
\end{tabular}

becomes pregnant, she is guilty. Such approaches and thoughts are wrong, because they can not cope with the circumstances and social pressures conspire against adolescents and make motherhood a likely result of its transition from childhood to adulthood. What is needed is a new way of thinking about the challenge of education in ways to prevent teenage pregnancy. Instead of seeing the girl as the problem and change their behavior as a solution, governments, communities, families and schools should consider the real challenges as poverty, gender inequality, discrimination, lack of access to services, and negative views about girls and men. It should see ways to reduce these problems in the adolescent, the pursuit of social justice, equitable development and the empowerment of girls and boys [12].

In general, efforts and resources to prevent pregnancy and sexually transmitted diseases in adolescents have focused on girls aged from 15 to 19 years. However, the girls more vulnerable and who face the greatest risk of complications and death due to pregnancy, abortion and childbirth, they are 14 years or younger. This group of very young adolescents is often overlooked by national health institutions, education and development or is beyond your reach, because generally these girls are in forced marriages 
and are prevented from attending school or have access to sexual health services and reproductive. Their needs are immense, and governments, civil society, communities and the international community must do more to protect them and support their safe and healthy transition from childhood and adolescence to adulthood [20]-[22].

There is however an ancient belief and that remains in developing countries, blaming the girl in the acts that involve sex and pregnancy. On the other hand, everyone has the notion that to generate child naturally, it takes competition to a man. We intend with this investigation, to highlight once again the intervention to be made as sexual education in schools should both men and women, are necessary for the occurrence of a pregnancy, desired or undesired. Therefore knowledge of the genitals, their function and the use of contraceptive methods, are required field if we are to build a just society [23]-[25].

Hospitals reports show the number of girls who undergo curettage post-abortion each year and who die as a result despite the abortion is prohibited in Angola [8].

Investments in human being are the key to protect these rights. Such investments not only help girls realize their full potential, but also part of the responsibility of a government to protect the rights of girls in accordance with the treaties and human rights instruments such as the Convention on the Rights of the Child, and with international agreements, including the International Conference Programme of Action on Population and Development of 1994, which continues to guide the work of UNFPA today [26].

\section{Conclusions}

In the absence of sexual education programs in general education system in Angola and there are still taboos in sexuality theme approach with adolescents, the results show no confidence on students to express their perceptions and feelings; they do not know the constitution of his genitals and how to prevent sexually transmitted diseases and unwanted pregnancy, a considerable number already practicing sex and using no contraceptive methods. The sample was made up of a total of 386.

The age prevailing was the range of 14 - 16 years with a total of 143 followed by students 11 - 13 within 124. Marital status the single was the largest with 360 and occupation only students with 388 . As the history of sexuality, if have had sex, already pregnant, have had abortion, two thirds of the girls said no; more than a third said regular menstrual period and had their first period between 11 to 13 years; the age of first sexual relations, even where it reaches, more than two thirds of the students left without answering; those who answered yes to the penetration, most were of the CICA and São Francisco de Assis. Knowledge of three contraceptive methods, the behavior was similar, almost two thirds did not respond and those mentioned mostly were from CICA and the condom was the most mentioned. No one could name three contraceptive methods. Knowledge of the sexual organs and functioning was classified as bad for everyone, both to themselves as the opposite sex.

\section{Recommendations}

- The Government of Huambo Province: support the initiative of the project sub- 
mitted to in the near future to include sexual education as a discipline in general education and that is comprehensive to the whole province.

- The Ministry of Education: approval of defined programs on sexual education in schools of general education and its urgent implementation at national level.

- The Ministry of Health: to increase the capacity and availability of technicians to promote and prevent the population on issues related to reproductive and sexual health.

- Families and society: to break the silence and taboos and start a frank and honest dialogue since childhood in regard to sexuality.

\section{Conflicts of Interest}

The authors have no conflicts of interest to declare.

\section{Funding}

There was no fund for research.

\section{Ethical Approval}

Research was conducted according to ethical principles, and was approved by the Scientific direction and Pedagogica the central Huambo hospital, Angola.

\section{References}

[1] Heilborn, M.L. (2003) Strange in the Nest: Sexuality and Research Trajectory. In: Old, G. and Kuschnir, K. (Eds.), Urban Research, Jorge Zahar Ed, Rio de Janeiro, 190-207.

[2] Diniz, D., Correa, M., Squinca, F. and Braga, K.S. (2009) Abortion: 20 Years of Research in Brazil. Cad Public Health, 25, 939-942. www.scielo.br/scielo.php?script=sci nlinks\&ref=000072\&pid=S1413...lng

[3] Alan Guttmacher Institute (1994) Clandestine Abortion: A Latin American Reality. Alan Guttmacher Institute, New York.

[4] Alan Guttmacher Institute (AGI) (2008) Facts on Induced Abortion in the United States. In Brief, Guttmacher Institute, Nueva York.

[5] Almeida, P.N. (2015) Sexual Education of Young People and Preventing of Unwanted Pregnancy: Guide to High School Students of Angola. Mayamba Publisher, Luanda.

[6] Lloyd, C. (2006) Schooling and Adolescent Behavior in Developing Countries. Population Council, New York.

[7] Souza, V.L.C., Correa, M.S.M., Souza, S.L. and Beserra, M.A. (2001) The Abortion among Adolescents. Revista Latino-Americana de Enfermagem, 9, 42-47. http://dx.doi.org/10.1590/S0104-11692001000200006

[8] Tavares, H.P., Tavares, S.B.M.P. and Silva, L.G.P. (2015) Teenage Pregnancy and Adverse Effects in the Province of Hbo-Angola. New Scholarly Publishing, 11, 63-68.

[9] Parker, R.G. (2000) Bodies, Pleasures and Passions: Sexual Culture in Contemporary Brazil. Editora Best Seller, São Paulo.

[10] Foucault, M. (1984) The History of Sexuality. 11th Edition, Grail, Rio de Janeiro.

[11] Giddens, A. (1993) The Transformation of Intimacy: Sex, Love and Eroticism in Modern Societies. Editora UNESP, São Paulo. 
[12] Population Council and UNFPA (2013) Good Practices: 2012 Competition, Adolescents \& Youth. UNFPA, Nova York. www.popcouncil.org/projects/244 CreateOpportunitiesMayan.asp .

[13] Rigol, O. (2010) Obstetricia y ginecología. Vol.1 3rd Reprint Edition, Medical Sciences, Ciudad de La Habana.

[14] Juarez, F., et al. (2005) The Incidence of Induced Abortion in the Philippines: Current Level and Recent Trends. Perspectivas Internacionalesen Family Planificación, 3, 140-149. Guttmacher Institute, Nueva York: 2006.

[15] Grimes, D.A., Benson, J., Singh, S., Romero, M., Ganatra, B., Okonofua, F.E. and Shah, I.H. (2006) Friday Unsafe Abortion: The Preventable Pandemic. The Lancet, 368, 1908-1919. http://dx.doi.org/10.1016/S0140-6736(06)69481-6

[16] Pinto, S.M.S. (2010) Knowledge and Behaviors to HIV/AIDS in Students Superior. Ponte Teaching Lima. http://revistas.ulusofona.pt/index.php/revistasaude/article/viewFile/679/571

[17] Hakkert, R. (2001) Preferences Reproductive en Adolescents. In: Guzman, J.M., et al., Eds., Diagnosis Salud Sexual y Reproductive Adolescents in Latin America y Caribbean, UNFPA, Mexico, DF, 41-56.

[18] Araújo, M.J. (1998) Legal Services Deployment in the Prospects of Reproductive Rights. In: Batista, C. and Laranjeira, M., Orgs., Abortion: Challenges of Legality, SOS BODY, Recife, 28-30.

[19] Saavedra, J. and Garcia, S. (2012) Impacts of Conditional Cash Transfer Programs on Educational Outcomes in Developing Countries: A Metaanalysis. Rand Labor and Population Working Paper.

http://www.rand.org/content/dam/rand/pubs/working papers/2012/RAND WR921-1.pdf

[20] Pathfinder International (2011) Prachar: Advancing Young People's Sexual and Reproductive Health and Rights in India. Pathfinder International, New Delhi.

[21] Panday, S., Makiwane, M., Ranchod, C. and Letsoalo, T. (2009) Teenage Pregnancy in South Africa-With a Specific Focus on School-Going Learners. Child, Youth, Family and Social Development, Human Sciences Research Council (Council for Research on Children, Youth, Family and Social Development and Human Sciences). Department of Basic Education, Pretoria.

[22] Save the Children (2007) Boys for Change: Moving towards Gender Equality. Save the Children, Stockholm.

[23] Winner, B., et al. (2012) Effectiveness of Long-Acting Reversible Contraception. New England Journal of Medicine, 366, 1998-2007. http://dx.doi.org/10.1056/NEJMoa1110855

[24] Tavares, et al. (2016) Obstetric, Sociodemographic, and Psychosocial Problems of Postpartum Adolescents of Huambo, Angola. Clinical Medicine Insights: Women's Health, 9, 13-19. http://dx.doi.org/10.4137/CMWH.S27161

[25] Abramovay, M., Castro, M.G. and Silva, L.B. (2004) Youth and Sexuality. UNESCO, Brasilia.

[26] Hill, K., et al. (2007) Estimates of Maternal Mortality Worldwide between 1990 and 2005: An Assessment of Available Data. The Lancet, 370, 1311-1319. http://dx.doi.org/10.1016/S0140-6736(07)61572-4 
Submit or recommend next manuscript to SCIRP and we will provide best service for you:

Accepting pre-submission inquiries through Email, Facebook, LinkedIn, Twitter, etc. A wide selection of journals (inclusive of 9 subjects, more than 200 journals)

Providing 24-hour high-quality service

User-friendly online submission system

Fair and swift peer-review system

Efficient typesetting and proofreading procedure

Display of the result of downloads and visits, as well as the number of cited articles

Maximum dissemination of your research work

Submit your manuscript at: http://papersubmission.scirp.org/ 